\title{
Moterų karių karjera Lietuvos kariuomenėje: moterų puskarininkių nuomonè
}

\author{
Deimantas Pleskys \\ Lietuvos Respublikos krašto apsaugos ministerija \\ Totoriu g. 25, LT-01121 Vilnius \\ Jūratė Guščinskienè \\ Generolo Jono Žemaičio Lietuvos karo akademija \\ Šlo g. 5A., LT-10322 Vilnius \\ cross $^{\text {ref }}$ http://dx.doi.org/10.5755/j01.ppaa.20.3.29292
}

\begin{abstract}
Anotacija. Šio straipsnio tikslas - ištirti moteru kariu karjeros galimybes Lietuvos kariuomeneje. Straipsnyje aptariama karjeros samprata, kariu karjeros teisinis reglamentavimas. Empirine straipsnio dalis remiasi originaliu moteru puskarininkiu nuomonès tyrimu, kuris buvo atliktas $2019 \mathrm{~m}$. pabaigoje mechanizuotoje pèstininku brigados vadovybejje „, Geležinis Vilkas“. Ištyrus moteru puskarininkiu nuomonę nustatyta, kad teisine bazé, reglamentuojanti kariu karjerq Lietuvos kariuomeneje, yra vienoda tiek moterims, tiek vyrams, tačiau dalis tyrimo dalyviu nurodè, kad ši bazè yra nepakankamai palanki néščioms ir vaiku priežiūros atostogose esančioms moterims, nes, pavyzdžiui, vaiku priežiūros atostogose esančios moterys neretai perkeliamos i personalo rezerva, o ju pareigas užima kiti kariai ir pan. Tiriamuju nuomoné apie moteru galimybes, lyginant su vyrais, siekti karjeros Lietuvos kariuomenèje išsiskyrè, nes dalis tyrimo dalyviu manè, jog moteru ir vyru galimybès yra lygios visose ju profesinès veiklos srityse, o kitos teigé, kad galimybès lygios tik administravimo, aptarnavimo ir panašiose sferose. Nustatyta, kad daliai moteru puskarininkiu yra sunku lygiomis sąlygomis su vyrais siekti vertikalios kario karjeros, kad mažai moteru kariu užima vadovaujančias pareigas kariuomeneje, $t$. $y$. siekiant vertikalios karjeros moterys neretai susiduria su „stikliniu lubu“ fenomenu. Taip pat nustatyta, kad kariuomeneje moterims karèms egzistuoja geresnès galimybès siekti horizontalios karjeros. Prie moteru karjera kariuomenèje skatinančiu veiksniu galima priskirti ju asmenine motyvacija bei finansines, materialines ir nematerialines paskatas, o prie trukdančiu - kariuomenèje vis dar egzistuojančius stereotipus, vadu asmeniškumus, moteru neittraukima $i$ sprendimu prièmimo procesa ir $\mathrm{kt}$.
\end{abstract}

Raktažodžiai: karjera, kariuomene, moteru puskarininkiu karjera

Keywords: career, army, career of female non-commissioned officers

\section{Ivadas}

Kariuomenė yra svarbi valstybès dalis. Tai dinamiška ir besikeičianti organizacija, užtikrinanti šalies saugumą, turinti išskirtinę struktūrą ir funkcijas. Karinès pajègos iš modernių tampa postmoderniomis, todėl kinta požiūris ị moterų dalyvavimą karinèje veikloje. Dar neseniai tiesioginis moterų vaidmuo mūsų šalies kariuomenejje buvo neįsivaizduojamas, nes kariuomenè buvo laikoma grynai „vyriška“ profesinès veiklos sritimi. Tuo tarpu dabartiniu laikotarpiu, kaip teigia Duncason ir kt. (2016), kariuomenè tapo viena iš „vyriškos profesijos“ sričių, kurią buvo „uzurpavusi“ vyriška lytis ir kuri vis labiau domina moteris. Moterys yra tapusios neatskiriama NATO narių karinių pajègų dalimi.

Situacija Lietuvoje po Nepriklausomybès atgavimo kito. 1998 m. prièmus LR Moteru ir vyru lygiu galimybiu istatyma (1998), buvo sudarytos teisinès prielaidos realiai užtikrinti lygių moterų ir vyrų teisių ịgyvendinimą. Minètas įstatymas oficialiai įtvirtino moterų teisę tarnauti kariuomenèje. Nuo 2000 m. ị Generolo Jono Žemaičio Lietuvos karo akademiją (toliau - LKA) studijuoti buvo 
pradètos priimti ir moterys, nes iki tol studijuoti šioje karinejje mokykloje galëjo tik vyrai. Nors pagal LR karo prievolès istatyma (1996, $2019 \mathrm{~m}$. suvestinè redakcija) i privalomają karo tarnybą moterys nèra šaukiamos, tačiau jos, pareiškusios savo norą raštu, gali tapti karo prievolininkèmis. Lietuvos kariuomenę reglamentuojančiuose teisès aktuose neakcentuojama jokių pareigų, kurių šalies karinėse pajègose negalètų eiti moterys (išskyrus nèščiąsias, neseniai pagimdžiusias ir krūtimi maitinančias).

Kariuomenè yra specifinė organizacija, kuri jaučia poreiki išnaudoti moterų potencialą, formuojant kuo profesionalesni karini personalą. Moterų padėtis kariuomenejje yra specifiška, nes joje moterys, lyginant su vyrais, sudaro mažumą. Nepaisant to, šiuolaikinès kariuomenès jaučia didejjantį moterų, kaip karinio personalo, poreikị. Kariavimo pobūdis keičiasi - tobulèja ginklai, kurių naudojimui nereikia vyriškos jègos (pvz., atsiranda naujų karo specialistų (kibernetinio saugumo, propagandos ir kt.) ir pan. (Hayward, 2018)). Visa tai formuoja poreiki moteris integruoti $\mathfrak{i}$ kariuomenę ir sudaryti sąlygas joms čia siekti karjeros. Kariuomenei reikia profesionalių igūdžių, kurių turi ne tik vyrai, bet ir moterys. Pasak Hayward (2018), tobulejjant karinėms technologijoms ir keičiantis karo pobūdžiui (kariavimas ịgyja nuotolinị, virtualų pobūdị ir kt.), asmens fizinè jèga tampa nebe pagrindiniu karinio meistriškumo kriterijumi, todėl tai didina lyčių integracijos ị kariuomenę galimybes. Technologiniai patobulinimai formuoja specializuotų žinių poreikị, todèl įdarbindamos abiejų lyčių asmenis karinès pajègos gali formuoti profesionalesni personalą. Dabartiniam laikmečiui būdingas kariuomenès orientacijos virsmas iš modernios i postmodernią: postmoderni orientacija toleruoja ir pripažịsta moterų vaidmenị kariuomenèje. Moterų pritraukimas ị karines pajègas laikoma postmodernios kariuomenès personalo formavimo strategija, kuriai igyvendinti reikia skatinti moteru karių motyvaciją karinei tarnybai (Vileikienè ir kt., 2015).

Statistiniai duomenys liudija, kad moterys yra tapusios svarbia Lietuvos kariuomenès dalimi. Krašto apsaugos ministerijos (toliau - KAM) Personalo departamento $2019 \mathrm{~m}$. sausio mènesio duomenimis, moterys sudarė 12,1 proc. $(2010 \mathrm{~m}$. $-11,1$ proc.) šalies profesinès karo tarnybos (toliau - PKT) karių, 237 iš jų yra karininkès (22,5 proc. nuo visų karininkų, o 2010 m. - tik 59, t.y. 10,7 proc. nuo visų karininkų), aukščiausias joms suteiktas laipsnis 2019 ir $2010 \mathrm{~m}$. - pulkininko leitenanto (2019 m. buvo 6, o 2010 m. - 2 moterims). Taigi, per 10 metų moterų karininkių skaičius padidèjo 4 kartus, o santykis tarp vyrų karininkų ir moterų karininkių pagerejjo moterų naudai, tačiau bendras santykis tarp vyrų ir moterų, tarnaujančių šalies profesinèje karo tarnyboje, beveik nepasikeitè.

Pagal NATO kodus karininkų kariniai laipsniai grupuojami nuo OF 1 iki OF 8, kur OF trumpinys reiškia „karininkas“, o skaičius nusako karinio laipsnio pavadinimą. Jaunesnieji karininkai: leitenanto ir vyresniojo leitenanto karinis laipsnis - OF 1 ir kapitono karinis laipsnis - OF 2. Vyresnieji karininkai: majoro karinis laipsnis - OF 3; pulkininko leitenanto karinis laipsnis - OF 4 ir pulkininko karinis laipsnis - OF 5. Generoly kariniai laipsniai: brigados generolo karinis laipsnis - OF 6; generolo majoro karinis laipsnis - OF 7 ir generolo leitenanto karinis laipsnis - OF 8.

NATO nacionalinių ataskaitų santraukose (Summary of National Reports of NATO..., 2016; Summary of National Reports of NATO..., 2017; Summary of National Reports of NATO..., 2019) ir KAM dokumentuose (KAM personalo departamento duomenimis, 2019) užfiksuota, kad Lietuvos kariuomenejje $2017 \mathrm{~m}$. nebuvo moterų, turinčių pagal NATO standartus OF 6 ir aukštesnius (generolų) karinius laipsnius. Beveik dvigubai daugiau vyrų negu moterų turèjo OF 3-5 (vyresniujų karininkų) karinius laipsnius. OF 1-2 (jaunesniųų karininkų) karinius laipsnius turèjo daugiau moterų negu vyrų. Puskarininkių ir kareivių bei grandinių laipsnius turinčių moterų skaičius buvo panašus kaip ir vyrų (4-5 proc. skirtumas). Norint veiksmingai integruoti moteris ị kariuomenę, reikia joms sudaryti palankias sąlygas siekti profesinès karjeros ir jos turi žinoti, kad egzistuoja reali kilimo karjeros laiptais galimybè.

Temos aktualumą liudija ir tai, kad moterų karjera kariuomenėje yra svarbus mokslininkų atliekamų teorinių studijų ir empirinių tyrimų objektas, nors tokių tyrimų kol kas nèra daug. İvairių šalių mokslininkai analizavo moterų karjeros galimybes kariuomeneje, pavyzdžiui, Duncanson ir Woodward (2016) bei Hayward (2018) akcentavo gerejančias moterų karjeros galimybes NATO narių ar kitų užsienio šalių kariuomenėse; Aleknevičienè (2013a ir b) pateikè lygių vyrų ir moterų karjeros galimybių Lietuvos krašto apsaugos sistemoje analizę; Aleknevičienè ir kt. (2012) atliko 
moterų ir vyrų socialinės, ekonominès ir psichologinės padėties skirtumų Lietuvos krašto apsaugos sistemoje analizę, kurios pagrindu pristatè moterų karjeros galimybes Lietuvos krašto apsaugos sistemoje; Orenius ir Pitrènaitè (2005) bei Maslauskaitė (2006) tyrè moterų karjeros situaciją Lietuvos kariuomenèje; Kamarck (2016) bei Rosellini ir kt. (2017) tyrè ịvairius moterų karjeros siekimo karinėse struktūrose sunkumus. Nors moterų integracija ị karines pajègas yra prioritetinis NATO narių karinio personalo formavimo objektas, dèl darbo rinkos segregacijos, lyčių diskriminacijos ir stereotipinio profesijų skirstymo i „,moteriškas“ bei ,vyriškas“, moterims sunku lygiomis sąlygomis konkuruoti su vyrais, siekiant karjeros kariuomeneje. Moterų karjera Lietuvoje kariuomenèje yra sudėtinga, nes šalies karinèse pajègose tarnaujančių moterų nèra tiek daug kiek vyrų, jų skaičiaus didejjimo procesas nèra spartus. Ypač sunku moterims siekti karjeros aukščiausiuose karinès vadovybės sluoksniuose ir gauti aukščiausio rango karinius laipsnius. Tokia situacija suponuoja problemini klausimą: kokios yra moterų karių karjeros galimybès Lietuvos kariuomeneje?

Tyrimo objektas: moterų karjera kariuomenejje.

Tyrimo tikslas - išanalizuoti moterų karių karjeros galimybes Lietuvos kariuomenèje.

Tyrimo uždaviniai: išnagrinèti karjeros sampratą; išanalizuoti teisinę bazę, reglamentuojančią karių karjerą Lietuvos kariuomenejje; ištirti moterų puskarininkių nuomonę apie moterų karjerą kariuomenejje.

Tyrimo metodai: mokslinès literatūros analizè, teisinių dokumentų apžvalga, statistinių duomenų analizè, interviu turinio analizè.

\section{Karjeros samprata}

Karjera yra neatsiejamas žmogaus gyvenimo atributas. Tai reiškinys, su kuriuo žmogus susiduria rinkdamasis profesinès veiklos sritị ir dalyvaudamas joje. Neary ir kt. (2016, p. 13) mano, kad karjera yra tai, kas išreiškia kontekstą, atspindintį, kaip žmonės gyvena skirtingose situacijose ir aplinkoje - karjera vienaip ar kitaip veikia ịvairias žmogaus gyvenimo sritis, ịskaitant švietimą, darbą, šeimą ir laisvalaikị. Siekdami karjeros žmonès turi derinti savo gyvenimo, darbo ir mokymosi pasirinkimus bei patirtis visais amžiaus ir gyvenimo tarpsniais. Petkevičiūtès $(2013$, p. 7) teigimu, karjera yra stimulas, kuris motyvuoja asmenį siekti geresnių darbo rezultatų ir tęsiasi visą žmogaus gyvenimą.

Karjeros sąvoka, Lamanausko ir Augienès (2015a, p. 8) nuomone, yra daugiaprasmè, kadangi apibrèžia ne tik profesinès veiklos pobūdį, bet ir dirbantị individą, jo socialinị statusą ir instituciją, kuri apibūdina dirbančiojo veiklą ir poziciją organizacijos struktūroje. Karjera, Petkevičiūtès (2007, p. 95-96) įsitikinimu, tradiciškai gali būti apibrěžiama asmens per darbo metus nuosekliai ịvykdytais darbais, kurie pasireiškia kilimu profesinès hierarchijos laiptais, padidejjusia individo galia ir prestižu visuomenèje. Pabrèžtina, kad nereikètų karjeros suprasti vien tik kaip pareigų paaukštinimo (vertikalaus kilimo pareigose). Raudeliūno ir Valicko (2018, p. 299), Gražulio ir kt. (2012, p. 254) teigimu, šiuolaikiniu požiūriu karjera apima ir pareigų keitimą ar mokymąsi, siekiant ịgyti asmeniui ir organizacijai prasmingų bei reikalingų darbo patirčių, kurios reikiamu metu užtikrintų reikalingą kompetencijų lygị. Siekiant detalesnès karjeros sampratos analizės, pateikiami vyraujantys moksliniai karjeros apibrèžimai (žr. 1 lentelę).

\section{Lentele 1. Karjeros apibrëžimai}

\begin{tabular}{|c|c|}
\hline ŠALTINIAI & KARJEROS APIBRĖŽIMAI \\
\hline Hambly, Bomford (2019, p. 7) & $\begin{array}{l}\text { Tai ịvairios priemonès, kuriomis asmuo gali išreikšti save ir dalyvauti } \\
\text { visuomenės gyvenime, nesvarbu, ar tai būtų darbas už atlyginimą, ar darbas } \\
\text { bendruomenejje, ar savanoriškas darbas. Karjera yra galimybė išnaudoti } \\
\text { žmogaus potencialą per formalujį ir savaimini mokymąsi bei tobulejjimą. }\end{array}$ \\
\hline $\begin{array}{c}\text { Guščinskienè, Čiburienè } \\
(2018, \text { p. } 177)\end{array}$ & Tai „,visą gyvenimą trunkanti asmens darbo ir mokymosi patirčių seka“. \\
\hline
\end{tabular}




\begin{tabular}{|c|l|}
\hline ŠALTINIAI & \multicolumn{1}{c|}{ KARJEROS APIBRĖŽIMAI } \\
\hline Gražulis ir kt. (2015, p. 273) & $\begin{array}{l}\text { Tai „pažangi, individo gyvenimo kontekste lokalizuojama darbo ir su juo } \\
\text { susijusių mokymosi patirčių seka, besiformuojanti individui palaikant bei } \\
\text { plètojant darbo santykius su organizacijomis“. }\end{array}$ \\
\hline Korsakienė ir kt. (2011, p. 178-179) & $\begin{array}{l}\text { Tai visą gyvenimą trunkanti darbu seka, siejama su individo pažiūromis ir } \\
\text { motyvais; tai elgsenų seka, siejama su darbine viso gyvenimo patirtimi. }\end{array}$ \\
\hline Petkevičiūtė (2007, p. 96) & $\begin{array}{l}\text { Tai „visą gyvenimą besitęsianti darbų seka, susijusi su asmens, dirbančio } \\
\text { tuos darbus, pažiūromis ir motyvais“. }\end{array}$ \\
\hline
\end{tabular}

Šaltinis: sudaryta autoriu, remiantis Hambly, Bomford (2019, p. 7), Guščinskiené, Čiburienė (2018, p. 177), Gražulis ir kt. (2015, p. 273), Korsakienè ir kt. (2011, p. 178-179), Petkevičiūtè (2007, p. 96)

Apibendrintai galima teigti, kad karjera šiuo metu dažniausiai siejama su asmens darbo ir mokymosi patirčių seka, kuri reiškiasi visą žmogaus gyvenimą. Tai yra moderni samprata, reiškianti, kad karjera yra tęstinè (t. y. trunka visą žmogaus gyvenimą), ji yra grindžiama patirtimis, kurias asmuo igyja mokymosi ir darbo procesuose.

Ilgą laiką tyrėjai savo dèmesị koncentravo ị konservatyvią (biurokratinę) karjeros koncepciją, kuria remiantis buvo skiriamos dvi karjeros rūšys organizacijose (Petkevičiūtè, 2013, p. 15-16): 1) vertikalioji karjera, pasižyminti darbuotojo kilimu organizacijoje pagal hierarchinę sistemą: individui paskiriamos aukštesnès pareigos, deleguojama daugiau teisių, pakeliamas atlyginimas; 2) horizontalioji karjera, reiškianti darbuotojo veiklą organizacijoje, kuri nesibaigia paaukštinimu. Darbuotojas organizacijoje atlieka daugiau funkcijų, turi daugiau darbo. I visa tai įeina kvalifikacijos kèlimas ir kompetencijos stiprinimas, kuriuos darbuotojas pasiekia per mokymus, seminarus, konferencijas ir kt.

Šiandieninèje visuomenejje, Korsakienès ir Smaliukienès (2014, p. 90) nuomone, karjeros klausimu demesys yra nukreiptas ị asmens savybes, jo fizinị ir psichologinị mobilumą, be to, asmuo neretai išsikelia kitus, nefinansinius karjeros tikslus. Pagrindinis šiuolaikinès karjeros požymis yra siekis suderinti darbuotojo ir organizacijos interesus. Tyrejjai pastebi, kad darbuotojų karjerą veikia įvairūs veiksniai. De Vos, Vander Heijden ir kt. (2018) teigia, kad karjerai pagrindinę įtaką daro tokios dimensijos - asmuo (individualūs veiksniai), kontekstas (aplinkos veiksniai) ir laikas (susijęs su pokyčiais asmens gyvenime ir aplinkoje). Dinamiška asmens, jo aplinkos ir laiko tèkmèje vykstančių pokyčių sąveika sudaro pagrindą karjeros raiškai. Lamanauskas ir Augienė (2015b, p. 107) taip pat mano, kad karjeros veiksnius galima suskirstyti $\mathfrak{i}$ vidinius (asmenybinius) ir išorinius. Vidiniai veiksniai padeda asmeniui įsisąmoninti savo karjeros siekimo poreikius (tai - įsitikinimai, gebejjimai, interesai, vertybès, savęs suvokimas, polinkiai, žinios apie darbo pasaulị, sveikata, asmenybė, vertybès, lytis ir kt.). Išoriniai veiksniai padeda asmeniui suprasti su karjera siejamą socialinį kontekstą (tai - šeima, žiniasklaida, draugai, mokymo įstaiga, bendruomenè, darbo rinka ir kt.).

Hirschi ir kt. (2018) mano, kad sėkmingai karjerai ịtaką daro keturios veiksnių grupès: 1) žmogiškasis kapitalas (bendros žinios, profesinès žinios ir žinios, kurių reikia darbo rinkai); 2) aplinka (karjeros galimybès organizacijoje, organizacinè ir socialinè parama karjerai, darbo iššūkiai); 3) motyvacija (asmens suinteresuotumas siekti karjeros, pasitikejjimas savo jëgomis, aiškūs karjeros siekimo tikslai); 4) karjeros valdymo elgsena (asmens įsitraukimas ị socialinius tinklus, informacijos apie karjeros galimybes rinkimas, mokymasis).

Pastebėtina, kad siekdamos karjeros moterys kartais susiduria su „stiklinių lubų“ fenomenu. Anot Vilniškytès ir kt. (2018, p. 54), ,stiklinių lubų“ terminu bandoma apibūdinti trikdžius, kurie neleidžia moterims kilti karjeros laiptais <... „. „Stiklinės lubos“ yra ịvardijamos kaip globalus reiškinys, kai moterys, priešingai nei vyrai, yra neproporcingai susitelkusios žemesniojo lygio ir mažesnius ịgaliojimus turinčiose vadovaujančiose pareigose“. Minètą fenomeną aktyviai analizuoja užsienio šalių ir lietuvių tyrejjai, pavyzdžiui, Sharma ir Kaur (2019), Williams ir McGivern (2017), Evertson ir Nesbitt (2004), Vilniškyte ir kt. (2018), Šidlauskienè (2005) ir kt. Evertson ir Nesbitt (2004) išskiria struktūrines ir elgesio kliūtis, analizuodami „stiklinių lubų“ fenomeną, o Sharma ir Kaur (2019) įžvelgia tris kliūtis, t. y. asmenines, organizacines ir socialines. Pastebètina, kad kol nebus įveiktos įvairios kliūtys, trukdančios moterims lygiomis sąlygomis su vyrais siekti karjeros, tol 
jų sukauptos žinios, gebèjimai ir kompetencijos nebus visiškai panaudotos civilinès ar karinès organizacijos labui.

Apibendrinant galima teigti, kad karjera reiškia asmens darbo ir mokymosi patirčių seką, besitęsiančią visą žmogaus gyvenimą. Taigi, karjera yra tęstinè, ji grindžiama patirtimis, kurias asmuo igyja mokymosi ir darbo procesuose. Nors mokslininkai išskiria ịvairias karjeros veiksnių grupes ir jiems priskiriamus elementus, tačiau dažniausiai nurodomos dvi grupès - vidiniai (asmenybiniai) ir išoriniai veiksniai. Asmuo, vedinas savo vidinių poreikių ir atsižvelgdamas $\mathfrak{i}$ aplinkos daromą poveiki bei iššūkius, renkasi profesiją ir formuoja savo karjeros kelią. Moterys siekdamos karjeros kartais susiduria su „stiklinių lubų“ fenomenu.

\section{Karių karjeros teisinis reglamentavimas Lietuvos kariuomenẻje}

Pagrindinis teisès aktas, reglamentuojantis karinès karjeros procesą, yra $1998 \mathrm{~m}$. patvirtintas LR Krašto apsaugos sistemos organizavimo ir karo tarnybos įstatymas (1998) (toliau - KASOKTI), nustatantis Krašto apsaugos sistemos (toliau - KAS) organizavimo, valdymo ir kontrolès pagrindus, karo tarnybos atlikimo tvarką. Raudeliūnas ir Valickas (2018, p. 303) pastebi, kad nuo KASOKTI prièmimo pradžios buvo ívykdyti 55 šio ịstatymo pakeitimai, todèl daro prielaidą, kad taip fragmentiškai keičiant karo tarnybos santykių reguliavimą, buvo stokojama sisteminio požiūrio ị karių karjeros valdymą. Kita vertus, galima pažymèti ir tai, kad per KASOKTI pakeitimus siekiama tobulinti karo tarnybos santykius. Minètas įstatymas reglamentuoja karių laipsnių skyrimo tvarką, karių tarnybos apmokejjimo ir aprūpinimo tvarką - visa tai turi įtakos kariams siekiant karjeros Lietuvos kariuomenèje. KASOKTİ 42 str. numatyta, kad PKT karys gali būti perkeliamas ị kitas pareigas vykdant rotaciją (horizontali karjera). KASOKTI 49 str. pateikiamos kariu kvalifikacijos tobulinimo nuostatos: PKT karių, karių savanorių ir kariūnų atrankos profesiniam parengimui, kvalifikacijos tobulinimui ar mokymuisi tvarką nustato krašto apsaugos ministras. Raudeliūno ir Valicko (2018, p. 304) nuomone, lyginant valstybės tarnautojų ir karių karjeros galimybes, pastebima, kad kariams yra taikoma gerokai daugiau tarnybos apribojimų. Neskaitant keleto išimtinių atvejų (pvz., kariams nedraudžiama ekonominè veikla, kuri yra susijusi su nuosavybès valdymu, verslo sukūrimu, individualia ar žemès ūkio veikla), kariams draudžiama dirbti kitą darbą. Karininko tarnybinio atlyginimo dydis priklauso tik nuo kario laipsnio. Vadinasi, du vienodą kario laipsni turintys karininkai, iš kurių vienas tarnauja taktiniame, kitas operaciniame ar net strateginiame KAS padalinio lygmenyje, gauna to paties dydžio tarnybini atlyginimą. Visa tai iškreipia karjeros siekimo sistemą, nes tarnybinis atlyginimas siejamas tik su kariniu laipsniu (vertikalia karjera), o ne su pareigomis (horizontalia karjera). Raudeliūnas ir Valickas (2018, p. 306) daro išvadą, jog karjera Lietuvos kariuomenèje turi būti „racionaliai valdomu reiškiniu, kai visoms suinteresuotoms šalims yra iš anksto žinoma už kokius nuopelnus, kompetencijas ir kvalifikacijas karininkai gali tikètis igyvendinti savo karjeros lūkesčius“. Pagal KASOKTI̦ (1998) moterų ir vyrų tarnybos sąlygos (atlyginimų, priedų ir kitų išmokų skyrimo ir mokèjimo, kitos materialinio aprūpinimo sąlygos) yra vienodos, taip pat moterims ir vyrams užtikrinamos vienodos socialinės garantijos. Tačiau moterims gali būti taikomos tam tikros tarnybos reikalavimų išimtys dèl su něštumu, kūdikio žindymu ir gimdymu susijusių aplinkybių (pvz., karo metu nèščios ir krūtimi maitinančios karès moterys negali būti šaukiamos ị tarnybą).

Lietuvos kariuomenè yra parengusi ir daugiau teisinių dokumentų, kuriais vadovaujasi reglamentuojant karių karjerą: KAS personalo politikos koncepcija (2017), Lietuvos kariuomenès logistinès krypties kareiviu ir puskarininkiu rengimo ir karjeros gairès (2016), Karininku karjeros koncepcija (2012).

KAS personalo politikos koncepcijoje (2017), kurioje apibūdinama bendra karinio personalo karjeros sistema ir joje galima išskirti svarbiausius KAS karinio personalo karjeros planavimo ir organizavimo politikos aspektus:

Karių karjera KAS susieta su vertikalios karjeros (apimančios aukštesnio karinio laipsnio ir/ar aukštesnių pareigu gavimą) ir horizontalios karjeros (didesnio kiekio funkcijų ir 
atsakomybiu suteikimo esamose pareigose, rotacijos, išvykimo i tarptautines operacijas ir pan.) galimybėmis $(25,28.1$ punktai).

Igyvendinama karių karjeros vadyba - tai „kario karjeros tikslų KAS formulavimo, jų igyvendinimo priemoniu nustatymo ir igyvendinimo koordinavimo procesas siekiant KAS ir asmeninių kario tikslų“ (3.4 punktas).

$\begin{array}{ll}\text { - } & \text { KAS rengiami individualūs karjeros planai PKT kariams (28.6.1 punktas). } \\ \text { - } & \text { Nustatomas karinio personalo kvalifikacijos ugdymo poreikis, ịtraukiant ị ugdymo ir }\end{array}$ kvalifikacijos tobulinimo planus. Karinis personalas gali dalyvauti karjeros, specialybės, kvalifikacijos tobulinimo ir kituose kursuose. „Kariams rengiami karjeros kursai, kuriuose igyjamos žinios ir igūdžiai, būtini vykdyti atitinkamo lygio pareigas ir gauti aukštesnį karinị laipsnį. KAS karinio personalo kvalifikacijos tobulinimas apima personalo rengimą konkrečioms užduotims ir pareigoms vykdyti, žinioms ir igūdžiams atnaujinti ir tobulinti““(23.3.2 punktas).

Lietuvos kariuomenés logistinès krypties kareiviu ir puskarininkiu rengimo ir karjeros gairèse (2016) (toliau - gairès) apibrèžiami kareivių ir puskarininkių (žemiausios ir vidurinès kariuomenès grandies) karjeros lygmenys. Šiame dokumente teigiama, kad karinè karjera - tai ,progresyvus procesas, kurio svarbiausias ịvertinimo rodiklis yra tam tikrą pareigų lygmeni atitinkantis karinis laipsnis" (Lietuvos kariuomenès logistinès krypties kareivių ir puskarininkių rengimo ir karjeros gairès, 2016, p. 4). Minètose gairèse (2.2.3 punktas) pateiktas Lietuvos kariuomenès kareivių ir puskarininkių karjeros modelis, sudarytas iš trijų tarpusavyje susijusių sričių blokų - rengimo, tarnybos eigos ir tarnybos standartų. Gairèse (2.2.4-2.2.6 punktai) taip pat teigiama, kad švietimo ir rengimo sritis formuoja reikalavimus kario gebejjimams, žinioms ir igūdžiams, būtiniems siekiant tinkamo tarnybos užduočių atlikimo. Kursai yra pagrindinẻ karių švietimo ir individualaus rengimo forma. Kareiviai ir puskarininkiai gali dalyvauti karjeros, specialybės ar kvalifikacijos kèlimo kursuose. Tarnybos standartų sritis yra tiesiogiai susijusi su kario laipsnio augimu. Kuo aukštesnis karinis laipsnis, tuo daugiau aukštesnių tarnybos ir profesinès veiklos reikalavimų atsiranda. Tarnybos eigos sritis apibrèžia kario karjeros progreso gaires. Kario siuntimas ị kursus, skyrimas $\mathfrak{i}$ pareigas ir karinio laipsnio suteikimas yra pagrindiniai kario karjerą igalinantys veiksniai.

Karininku karjeros koncepcijoje (2012) yra suformuluotos KAS karininkų karjeros sistemos gairès, organizavimo principai, koncepcijos igyvendinimo formos ir būdai. Šiame dokumente karjera suprantama, kaip „kario kilimas tarnyboje, pereinant ị aukštesnị lygị ir (ar) gaunant aukštesnị karinị laipsnį“ (5.4 punktas). Tai vertikalios karjeros sąvoką apibrèžiantis teiginys, nors minètos koncepcijos 39 punkte pripažịstama, kad pagal individualųjị karininko karjeros planą karininkas gali būti rotuojamas ị kitas pareigas, taikant vertikalios ar horizontalios rotacijos būdą.

Svarbi karinio rengimo sistemos grandis yra Generolo Jono Žemaičio Lietuvos karo akademija. Vienas iš svarbių LKA veiklos tikslų yra „vykdyti studijas, ugdančias karininkus, <..>, teikti moksliniais tyrimais grindžiamą šiuolaikinị pažinimo ir technologijų lygị atitinkantị aukštaji universitetinị išsilavinimą, aukštojo mokslo kvalifikaciją..." (LKA statutas, 2015, 10.1 punktas). Tuo tarpu LKA Strategijos 2018-2024 (2018) viena iš strateginių krypčių skelbia, kad būtina ,sudaryti sąlygas nuolat tobulinti edukacines, lyderystès ir dalykines kompetencijas pagal LKA ir KAS poreikius, igyvendinant mokymosi visą gyvenimą principą“ (LKA strategija, 2018, p. 7). Tokiu būdu LKA prisideda formuojant karininkų karjeros sistemos pagrindą, nes be tinkamo karinio pasirengimo jie negalètų siekti karjeros šalies kariuomenèje.

Apibendrinant galima teigti, kad Lietuvos kariuomenė turi teisinę bazę, reglamentuojančią karių karjerą, tačiau pastebètina, jog ši bazè kartais patiria tam tikrų pokyčių, kurie yra neišvengiami šiuolaikinèje dinamiškoje visuomenèje. Teisiniuose dokumentuose atsispindi moterų ir vyrų vienodos tarnybos sąlygos (atlyginimų, priedų ir kitų išmokų skyrimo ir mokejjimo, kitos materialinio aprūpinimo sąlygos), taip pat akcentuojama, kad moterims bei vyrams užtikrinamos vienodos socialinès garantijos. Kariuomenei būdingas biurokratinis požiūris ị karjerą. 


\section{Tyrimo metodika}

Siekiant išanalizuoti moterų karių požiūrị i karjeros galimybes Lietuvos kariuomenèje buvo atliktas empirinis tyrimas. Tyrimui pasirinkta konkreti karinè organizacija - mechanizuotoji pèstininkų brigados vadovybè (toliau - MPB) „Geležinis Vilkas“.

MPB „Geležinis Vilkas“ uždavinys - rengti karius LR sausumos teritorijos gynybai, siekiant užtikrinti valstybės teritorijos vientisumą, palaikyti karinių vienetų kovinę parengtị bei gebëjimus sąveikauti su sajungininkų pajėgomis, rengtis tarptautinėms operacijoms ir jose dalyvauti, teikti pagalbą valstybès ir savivaldybių institucijoms įstatymų nustatytais atvejais bei vykdyti kitas taikos meto užduotis (MPB „Geležinis Vilkas“ vidiniai duomenys, 2019).

Empirinio tyrimo tikslas: ištirti moterų puskarininkių, tarnaujančių MPB „Geležinis Vilkas“, nuomonę apie karjeros galimybes Lietuvos kariuomenèje.

Tyrimo metodai: interviu, turinio analizè.

Tyrimo proceso etapai: 1) sudarytas interviu klausimynas, remiantis išanalizuota teorine medžiaga ir išsikeltu tyrimo tikslu; 2) atlikta informančių atranka, remiantis išsikeltais tyrimo dalyvių atrankos kriterijais; 3) atlikti interviu su moterimis puskarininkėmis; 4) transkribuoti interviu garso įrašai; 5) atlikta tyrimo duomenų turinio analize; 5) suformuluotos tyrimo išvados.

Tyrimo instrumentas. Interviu klausimynas buvo parengtas remiantis atlikta teorine pasirinktos temos analize, t.y. Raudeliūnas ir kt. (2018), Wilén ir kt. (2018), Rosellini ir kt. (2017), Aleknevičienè (2013 a ir b), Maslauskaitė (2006), Orenius ir kt. (2005), Hirschi ir kt. (2018). Informančių moterų puskarininkių buvo klausiami atviri klausimai apie: teisinę bazę, reglamentuojančią karjeros galimybes Lietuvos kariuomenejje; moterų galimybes, lyginant su vyrais, siekti karjeros kariuomenejje; moterų karių galimybes siekti vertikalios ir horizontalios karjeros kariuomenëje; veiksnius, skatinančius ir trukdančius moterims siekti karjeros Lietuvos kariuomenèje.

Informančiu atranka. Atranka buvo vykdyta remiantis kokybinio tyrimo keliamais kriterijų atrankos būdais, kai tyrimo dalyviai pasirenkami pagal nustatytus konkrečius kriterijus, kurie atitinka temos probleminį kontekstą ir atspindi tyrimo problemos turinị (Žydžiūnaitè, 2011). Informantès buvo atrenkamos atsižvelgiant $\mathfrak{i}$ kelis kriterijus: lytis (moterys), tarnybos vieta (tarnyba MPB „Geležinis Vilkas"), tarnybos stažas (10 metų ar didesnis karinès tarnybos stažas) ir statusas (priklausymas kariniam personalui (turi kario statusą). Tyrimo imtis -8 moterys puskarininkès. Imties dydį lėmè pasiektas duomenų prisotinimo efektas, t.y. tiriamųjų atsakymai pradejo kartotis ir iš esmès neatskleidè naujų su tyrimu susijusių aspektų (Gaižauskaitè ir kt., 2016, p. 41).

Tyrimo etika. Atliekant tyrimą buvo laikomasi tyrejo etikos principų: pagarbos asmens privatumui, konfidencialumo ir anonimiškumo, geranoriškumo ir nusiteikimo nekenkti tiriamam asmeniui bei teisingumo principų (Žydžiūnaite ir kt., 2017, p. 340-349). Tyrèjai gavo tyrimo dalyvių sutikimus dalyvauti tyrime, jas supažindino su tyrimo aktualumu ir tikslu. Informantèms sutikus, jų atsakymai ị klausimus buvo ịrašyti ị diktofoną, o po to transkribuoti ir straipsnyje cituojami originalia kalba. Informantès buvo koduojamos (moteris puskarininkè: MP1, MP2 ir t. t.). Duomenų analizei taikytas turinio analizès metodas. Analizuojant buvo išskirtos kategorijos ir reikšmingos subkategorijos.

Tyrimas atliktas $2019 \mathrm{~m}$. lapkričio mėnesị.

\section{Tyrimo rezultatai ir jų aptarimas}

Sociodemografinès tiriamuju charakteristikos. Tyrime dalyvavusioms moterims karèms buvo būdingos ịvairios sociodemografinès charakteristikos.

Pagal išsilavinima tyrimo dalyvès pasiskirstè taip: 2 informantės yra igijusios aukštaji universitetinị išsilavinimą (MP1; MP4); 3 - aukštajį neuniversitetinị (MP2; MP6; MP7); 3 - vidurinị (MP3; MP5; MP8).

Pagal tarnybos stažą: mažiausią karinès tarnybos stažą - 10 metų - turëjo viena tyrimo dalyvè (MP4), 11 metų - dvi (MP5; MP8), 12 metų - dvi (MP2; MP6), 17 metų - viena (MP3); didžiausią 
karinès tarnybos stažą (18 metų) taip pat turèjo dvi tyrimo dalyvès (MP1; MP7). Tyrime dalyvavusių moterų karinès tarnybos stažo vidurkis - 13,6 metų.

Pagal turima karini laipsnị tyrimo dalyvès pasiskirstė taip: 2 informantės puskarininkès buvo grandinès (MP4; MP8), 2 - seržantès (MP5; MP6), 2 - vyresniosios seržantès (MP2; MP3), 2 - štabo seržantès (MP1; MP7).

Pagal šeimine padèti tyrimo dalyvès pasiskirstè taip: 6 informantès - ištekèjusios (MP1; MP2; MP4; MP5; MP6; MP7); 1- netekejjusi (MP8); 1- išsiskyrusi (MP3).

Galima teigti, kad visas tyrimo dalyves vienija tai, kad jos yra profesionalią karo tarnybą MPB „Geležinis Vilkas“ atliekančios moterys, kurios dèl savo darbo pobūdžio (karinès tarnybos) yra suinteresuotos siekti karjeros Lietuvos kariuomenèje.

Teisine bazè, reglamentuojanti karjera Lietuvos kariuomenëje. Tyrimo metu visu pirma buvo siekta nustatyti moterų puskarininkių nuomonę apie teisinę bazę, kuri lemia karjeros galimybes kariuomenèje. Kategoriją „Teisinè bazė, reglamentuojanti karjerą Lietuvos kariuomenèje“ sudaro trys subkategorijos (žr. 2 lentelę).

Lentelè 2. Teisinė bazè, reglamentuojanti karjerą Lietuvos kariuomenėje

\begin{tabular}{|c|c|c|}
\hline KATEGORIJA & SUBKATEGORIJA & İRODANTIS TEIGINYS \\
\hline \multirow{3}{*}{$\begin{array}{l}\text { Teisinė bazé, } \\
\text { reglamentuojant } \\
\text { i karjerą } \\
\text { Lietuvos } \\
\text { kariuomeneje }\end{array}$} & $\begin{array}{l}\text { Teisinè bazė vienodai } \\
\text { palanki moterims ir } \\
\text { vyrams }\end{array}$ & $\begin{array}{l}\text { „Teisinė bazė vienoda visiems, todèl ji yra palanki arba nepalanki vienodai } \\
\text { ir vyrams, ir moterims“(MP1); „Teisinèje bazèje nepastebejau palankumo } \\
\text { / nepalankumo lyties atžvilgiu“ (MP4). }\end{array}$ \\
\hline & $\begin{array}{l}\text { Teisinė bazė } \\
\text { nepalanki néščioms ir } \\
\text { vaikų priežiūros } \\
\text { atostogose esančioms } \\
\text { moterims }\end{array}$ & $\begin{array}{l}\text { „<..> vaikų auginimas kariuomenèje dirbančiai moteriai pristabdo jos } \\
\text { karjerą ar net pakeičia jos kryptị. Moteris, išejusi vaiko priežiūros } \\
\text { atostogų, yra perkeliama ị personalo rezervą ir tuomet ị jos pareigas gali } \\
\text { būti priimamas kitas karys. Grįžusiai po [vaiko auginimo] atostogų } \\
\text { moteriai ieškoma kita pareigybè, dèl to gali keistis karjeros kryptis“ } \\
\text { (MP7). }\end{array}$ \\
\hline & $\begin{array}{l}\text { Nevienodas teisės } \\
\text { aktų (norminių } \\
\text { dokumentų) } \\
\text { interpretavimas lyčių } \\
\text { atžvilgiu }\end{array}$ & $\begin{array}{l}\text { „<...> realiai, viskas priklauso ne nuo teisinio reglamentavimo, o nuo } \\
\text { žmogiškujų resursų, kadangi sprendimus priima atitinkamas personalas“ } \\
\text { (MP2); „Su teisinio reglamentavimo spragomis, kurios turètų itakos lygių } \\
\text { galimybių užtikrinimui, nesusidūriau, tačiau su norminių dokumentų } \\
\text { interpretavimu, }<\ldots>\text { kuomet sudaromos realiai neegzistuojančios kliūtys } \\
\text { siekti karjeros - taip“ (MP3). }\end{array}$ \\
\hline
\end{tabular}

Šaltinis: sudaryta autoriu.

Apibendrinant tyrimo dalyvių nuomonę apie teisinę bazę, reglamentuojančią karjerą Lietuvos kariuomenèje, galima teigti, kad daugiau nei pusė tyrimo dalyvių (6 moterys karès) teigè, kad teisinė bazè, reglamentuojanti karjerą Lietuvos kariuomenèje, yra vienoda moterims ir vyrams, todèl teisiniu požiūriu galimybès siekti karjeros abiejų lyčių atstovams yra palankios. Tačiau kai kurios tyrimo dalyvès (3 moterys karès) vis dèlto įžvelgè problemų moterims siekiant karjeros, kurios susijusios su nèštumo ir vaiko priežiūros atostogų laikotarpiais, nes tuo metu jos negali tobulintis (pvz., dalyvauti kursuose, seminaruose); moterys išéjusios vaiko priežiūros atostogu yra perkeliamos i personalo rezervą ir jų pareigas gali užimti kiti kariai, o grịžusioms po vaiko priežiūros atostogų moterims ieškomos kitos pareigybès, dèl to gali keistis jų karjeros kryptys. Vadinasi, moterys neretai yra priverstos rinktis prioritetą - šeimą arba karinę tarnybą (pasireiškia dvigubas lojalumas); tai vèliau turi ịtakos jų karjerai. Viena tyrimo dalyvė pastebejo skirtumą tarp karjeros teisinio reglamentavimo ir priimamų sprendimų bei akcentavo subjektyvų teisès aktų (norminių dokumentų) interpretavimą, kurie daro įtaką kario karjerai. Pastebėtina, kad žemesnio išsilavinimo moterys karès vis dèlto ne taip palankiai vertino teisinę bazę reglamentuojančią karjerą kariuomenèje, kaip turinčios aukštesnị išsilavinimą. Darytina prielaida, kad moterų karių požiūris i teisinę bazę, reglamentuojančią karjerą Lietuvos kariuomeneje, bent iš dalies priklausè nuo moterų karių ịgyto išsilavinimo. Nors teisès aktai užtikrina vienodas galimybes siekti karinès karjeros moterims ir vyrams, tačiau jie neužkerta kelio vadovybei priimti subjektyvius sprendimus ir proteguoti vyrus ị aukštesnes vadovaujančias pareigas. Nors teisinè bazè nesudaro formalių kliūčių moterims siekti karinès karjeros (iš dalies išskyrus 
besilaukiančias ir vaiko priežiūros atostogose esančias moteris kares), egzistuoja neformalios kliūtys, kurių teisès aktai nereglamentuoja.

Moteru galimybès, lyginant su vyrais, siekti karjeros Lietuvos kariuomenëje. Šioje kategorijoje tyrimo dalyvių atsakymai buvo sugrupuoti ị dvi subkategorijas (žr. 3 lentelę).

Lentelè 3. Moterų galimybès, lyginant su vyrais, siekti karjeros Lietuvos kariuomenėje

\begin{tabular}{|c|c|c|}
\hline KATEGORIJA & SUBKATEGORIJOS & IRODANTYS TEIGINIAI \\
\hline \multirow{2}{*}{$\begin{array}{l}\text { Moterų } \\
\text { galimybès, } \\
\text { lyginant su } \\
\text { vyrais, siekti } \\
\text { karjeros } \\
\text { Lietuvos } \\
\text { kariuomenèje }\end{array}$} & Lygios galimybės & $\begin{array}{l}\text { „Galimybès yra lygios“ (MP1); „Manau, kad taip. Išskirtinumo nėra kaip } \\
\text { moteriai. Tie patys reikalavimai kaip vyrams, kuriuos turi atitikti“ (MP3); } \\
\text { „Karjeros galimybés, mano nuomone, kariuomenėje yra lygios tiek vyrams, } \\
\text { tiek moterims“ (MP7). }\end{array}$ \\
\hline & Nelygios galimybės & 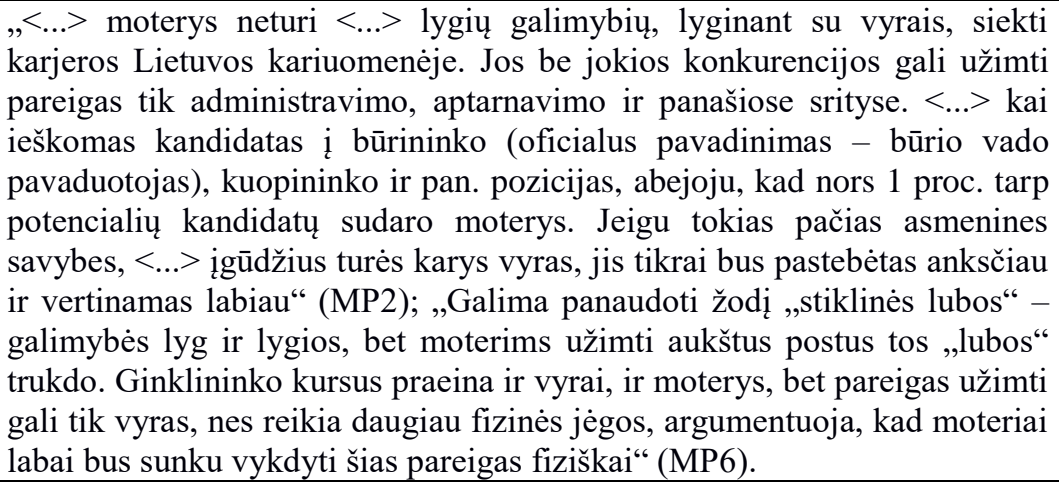 \\
\hline
\end{tabular}

Šaltinis: sudaryta autorių.

Ištyrus informančių nuomonę apie moteru galimybes, lyginant su vyrais, siekti karjeros Lietuvos kariuomenèje, buvo nustatyta, kad pusè tyrimo dalyvių (4 moterys karès) nurodè tai, kad moteru galimybès, lyginant su vyrais, siekti karjeros Lietuvos kariuomenejje yra lygios. Kita dalis tiriamųų (4 moterys karès) laikèsi priešingos nuostatos ir teigè, jog moterų galimybès, lyginant su vyrais, siekti karjeros mūsų šalies kariuomenejje nèra lygios, kad egzistuoja akivaizdus vyrų pranašumas prieš moteris, siekiant karjeros tam tikrose pareigose. Tokios priešingos nuomonès gali būti būdingos moterims, siekiančioms skirtingų karjeros aukštumų. Manytina, kad dalis moterų galbūt nesiekia karinès karjeros labai aukštose pareigose, todèl mažiau susiduria su vyrų pasipriešinimu. Ne visas tyrimo dalyves tenkina susiklosčiusi situacija, kuri yra palankesnè vyrams, o ne moterims. Viena tyrimo dalyvè pastebėjo Lietuvos kariuomenėje „stiklinių lubų“ reiškinį, kuris trukdo moterims karèms užimti aukštus postus. Lygios su vyrais moterų galimybės siekti karinès karjeros priklauso nuo to, kokioje srityje siekiama karjeros. Akcentuota, kad moterys kariuomenejje lengviau gali užimti aukštesnes pareigas tose srityse, kurios dažnai yra mažiau patrauklios vyrams, pavyzdžiui, personalo administravimo, aptarnavimo, ryšių, viešųjų ryšių ir panašiose srityse, tačiau joms sunku užimti būrio vado pavaduotojo, kuopininko, bataliono puskarininkio, ginklininko ir panašias pareigas.

Moterų kariu galimybès siekti vertikalios karjeros Lietuvos kariuomenëje. Šioje kategorijoje informančių atsakymai buvo sugrupuoti ị tris subkategorijas (žr. 4 lentelę).

Lentelè 4. Moterų karių galimybès siekti vertikalios karjeros Lietuvos kariuomenèje

\begin{tabular}{|c|c|c|}
\hline KATEGORIJA & SUBKATEGORIJOS & IRODANTYS TEIGINIAI \\
\hline \multirow[t]{2}{*}{$\begin{array}{c}\text { Moterų karių } \\
\text { galimybès siekti } \\
\text { vertikalios } \\
\text { karjeros Lietuvos } \\
\text { kariuomenejje }\end{array}$} & Realios galimybés & $\begin{array}{l}\text { „Man asmeniškai problemų nebuvo. Pasiekiau aukščiausią savo } \\
\text { pareiginį karinị laipsnį“ (MP1); „Siekimas vertikalios karjeros kaip } \\
\text { moteriai, manau, mane tenkina. Visa tai priklauso, kokiam etate esi } \\
\text { ir koks tavo siektinas laipsnis“(MP3); „<..> galimybė siekti karjeros } \\
\text { yra. Kartais tai priklauso nuo šeimyninių aplinkybių, kartais nuo } \\
\text { vadų požiūrio i moterị, be abejo, priklauso ir nuo pačios moters } \\
\text { siekių ir tikslų“ (MP7). }\end{array}$ \\
\hline & Ribotos galimybès & $\begin{array}{l}\text { „Asmeninè patirtis rodo, jog moteriai siekti vertikalios karjeros } \\
\text { Lietuvos kariuomeneje gana sudètinga“ (MP2); }\end{array}$ \\
\hline
\end{tabular}




\begin{tabular}{|c|c|c|}
\hline KATEGORIJA & SUBKATEGORIJOS & IRODANTYS TEIGINIAI \\
\hline & $\begin{array}{c}\text { Mažai moterų } \\
\text { vadovaujančiose } \\
\text { pareigose }\end{array}$ & $\begin{array}{c}\text { „Padalinyje yra po kelias moteris ir tikrai jos neužima vadovaujamų } \\
\text { ar kitų atsakingų postų“ (MP5); , , }<>\text { stengiamasi išvengti moterų } \\
\text { vadovaujančiose pozicijose“ (MP4). }\end{array}$ \\
\hline
\end{tabular}

Šaltinis: sudaryta autorių.

Apibendrinus informančių nuomonę apie moterų karių galimybes siekti vertikalios karjeros Lietuvos kariuomenèje, buvo nustatyta, jog pusè tyrimo dalyvių (4 moterys karès) nurodė, kad moterų karių galimybės siekti vertikalios karjeros Lietuvos kariuomenejje yra realios. Tai buvo tos pačios tyrimo dalyvès, kurios akcentavo, kad moterų galimybès, lyginant su vyrais, siekti karinès karjeros, yra lygios. Manytina, kad šių moterų karių lūkesčiai dẻl karinès karjeros yra bent iš dalies patenkinti, todèl šios informantès, besiremdamos savo patirtimi, geriau vertino moterų karių galimybes siekti vertikalios karjeros kariuomenèje.

Likusios tyrimo dalyvès (4 moterys karès), anot kurių, moterų karių galimybès siekti vertikalios karjeros kariuomenejje yra ribotos, pabrèžè, jog moterims siekti tokios karjeros yra gana sudėtinga, sunku ir ilgai užtrunka. Darytina prielaida, kad šių moterų karių lūkesčiai dèl karinès karjeros yra dideli, todèl jos labiau susiduria su nelygiomis lyčių galimybėmis, siekiant užimti aukštesnes vadovaujančias pareigas. Pusė moterų karių pabrèžė, kad yra mažai moterų karių, užimančių vadovaujančias pareigas kariuomenèje. Visa tai leidžia teigti, kad daliai moterų yra sunku lygiomis sąlygomis su vyrais siekti vertikalios karinès karjeros, ypač kai lūkesčiai dèl šios karjeros vertikalios karjeros yra dideli.

Moteru kariu galimybès siekti horizontalios karjeros Lietuvos kariuomenëje. Analizuojamoje kategorijoje tiriamujų atsakymai buvo sugrupuoti ị 6 subkategorijas (žr. 5 lentelę).

Lentele 5. Moterų karių galimybės siekti horizontalios karjeros Lietuvos kariuomenėje

\begin{tabular}{|c|c|c|}
\hline KATEGORIJA & SUBKATEGORIJOS & İRODANTYS TEIGINIAI \\
\hline \multirow{6}{*}{$\begin{array}{l}\text { Moterų karių } \\
\text { galimybės siekti } \\
\text { horizontalios } \\
\text { karjeros } \\
\text { Lietuvos } \\
\text { kariuomeneje }\end{array}$} & $\begin{array}{l}\text { Geresnès galimybès } \\
\text { siekti horizontalios } \\
\text { nei vertikalios } \\
\text { karjeros }\end{array}$ & $\begin{array}{l}\text { „Kadangi pati neseniai pradėjau horizontalią karjerą, tai šitoje srityje, } \\
\text { manau, tikrai yra galimybės siekti karjeros“ (MP5); „Galimybės yra. <...> } \\
\text { atėjau i kariuomenę pagal vienoki išsilavinimą ir tęsiau karjerą ta kryptimi } \\
\text { keletą metų, tačiau grịzusi po vaiko priežiūros atostogu gavau skirtingas } \\
\text { pareigas ir ėmiau mokytis, augti ir tobulèti visai kitoje srityje“ (MP7). }\end{array}$ \\
\hline & $\begin{array}{l}\text { Horizontalios } \\
\text { karjeros privalumai } \\
\text { moterims karems }\end{array}$ & $\begin{array}{l}\text { „Tokia karjera padeda igyti naujų igūdžių bei atskleisti savo išskirtines } \\
\text { savybes platesniam ratui asmenų, kurie, pastebejję potencialą, gali } \\
\text { pakreipti karjerą tinkama linkme arba sudaryti sąlygas jos siekti“ (MP2); } \\
\text { „<...> čia moterys daugiau turi galimybių atsiskleisti kaip profesionalès. } \\
\text { Pavyzdžiui, personalo srities ar medicinos, ryšių specialistės“ (MP8). }\end{array}$ \\
\hline & $\begin{array}{l}\text { Blogesnės galimybės, } \\
\text { lyginant su vyrais }\end{array}$ & $\begin{array}{l}\text { „Mums viską reikia daryti dvigubai geriau nei daro vyrai, turèti geresnị } \\
\text { išsilavinimą, tam tikras asmenines savybes, tuomet galimybių siekti } \\
\text { horizontalios karjeros atsiras daugiau“ (MP2); „[Šis karjeros modelis yra] } \\
\text { netgi naudojamas kaip „užliūliavimas“, nes dažnai „plaunamos } \\
\text { smegenys“ moterims ir įteigiamos tam tikros mintys bei karjeros kryptys“ } \\
\text { (MP4). }\end{array}$ \\
\hline & $\begin{array}{l}\text { Kursuc planavimo } \\
\text { problemos }\end{array}$ & $\begin{array}{l}\text { „Pavyzdžiui, jeigu nesi užsiplanavusi artėjančių naujų metų plane } \\
\text { tobulinimo igūdžių kursų (seminarai, atnaujinimo kursai ir t.t.), tada būna } \\
\text { nesuplanuotas finansavimas, tuomet tavęs nėra suinteresuoti siųsti ị tokius } \\
\text { kursus, jiems iš karto atsiradus. O susiplanuoti galbūt negalèjai dèl tam } \\
\text { tikrų iškilusių nesuplanuotų problemų“ (MP3). }\end{array}$ \\
\hline & $\begin{array}{l}\text { Karjeros sąsajos su } \\
\text { tarnybos sritimi }\end{array}$ & $\begin{array}{l}\text { „Horizontali karjera labai priklauso nuo tarnybos srities. Pvz., jei esi } \\
\text { pirkimų specialistas - i seminarus galima važiuoti kad ir kasmet, nes yra } \\
\text { naujovių. Kitose srityse dažniausiai lieka anglų kalbos atnaujinimo kursai } \\
\text { (kas yra labai gerai)“(MP1). }\end{array}$ \\
\hline & $\begin{array}{l}\text { Karjeros sąsajos su } \\
\text { asmeninėmis } \\
\text { savybėmis }\end{array}$ & $\begin{array}{l}\text { „[Horizontali] karjera itin glaudžiai susijusi ir su asmeninėmis moters } \\
\text { savybėmis“(MP2). }\end{array}$ \\
\hline
\end{tabular}

Šaltinis: sudaryta autorių. 
Gauti tyrimo rezultatai liudija, jog trys ketvirtadaliai tyrimo dalyvių (6 moterys karès) teigè, kad moterims karèms egzistuoja geresnès galimybès siekti horizontalios, nei vertikalios karjeros. Dažnai kariuomenėje organizuojami kursai ir seminarai, kvalifikacijos tobulinimas padeda gerinti profesinius įgūdžius ir augti savo profesinèje srityje. Dalis tyrimo dalyvių (2 moterys karès) pabrěžè horizontalios karjeros privalumus moterims karèms, pavyzdžiui, profesinių žinių demonstravimą, asmeninio tobulèjimo užtikrinimą, naujų ịūdžių igijimą, motyvacijos didinimą, „neužsibuvimą“ vienose pareigose, moterų kaip profesionalių potencialo atskleidimą ir kt. Dvi informantès pripažino, kad moterims siekti horizontalios karinès karjeros yra sunkiau negu vyrams. Jų nuomone, horizontali karjera naudojama kaip moterų „užliūliavimas“, nes karès taip nukreipiamos ị tam tikras karjeros kryptis (moterų horizontali karjera kariuomenejje naudojama kaip moteru vertikalios karjeros alternatyva, t. y. patenkinami moterų karių lūkesčiai dėl horizontalios karjeros, kad nereikètų tenkinti lūkesčiu dèl vertikalios karjeros). Viena tiriamoji nurodè, kad egzistuoja horizontalios karjeros, susijusios su karių siuntimu i tobulinimosi kursus ir seminarus, planavimo problemų. Manytina, kad ši problema būdinga ne tik moterims, bet ir vyrams, todèl nèra specifinè lyčių požiūriu. Dvi tyrimo dalyvès pabrèžè esant horizontalios karjeros sąsajas su karinès tarnybos sritimi ar asmeninėmis moters karès savybėmis.

Pateikti faktai leidžia teigti, kad daliai moterų yra sunku lygiomis sąlygomis su vyrais siekti horizontalios karjeros, tačiau tai atlikti yra lengviau, negu siekti vertikalios karjeros, t. y., egzistuoja mažiau neformalių kliūčių moterims karèms siekti horizontalios nei vertikalios karjeros.

Moteru karjerą Lietuvos kariuomenëje skatinantys veiksniai. Šioje kategorijoje buvo išskirtos trys subkategorijos (žr. 6 lentelę).

\section{Lentele 6. Moterų karjerą Lietuvos kariuomenẻje skatinantys veiksniai}

\begin{tabular}{|c|c|c|}
\hline KATEGORIJA & SUBKATEGORIJOS & IRODANTYS TEIGINIAI \\
\hline \multirow[t]{4}{*}{$\begin{array}{l}\text { Moterų karjerą } \\
\text { Lietuvos } \\
\text { kariuomenèje } \\
\text { skatinantys } \\
\text { veiksniai }\end{array}$} & Vidinė motyvacija & $\begin{array}{l}\text { „Nuolatinis noras ịrodyti, kad nesi prastesnè nei kiti bei noras būti } \\
\text { vertinamai už tai, kokia esi“ (MP2); „<...> asmeninès žinios, igytas } \\
\text { išsilavinimas ir individualūs gebejimai privalo būtu panaudoti Tévynès } \\
\text { labui, o ne dulkèti kažkur, po užrašu ,tik moteris“ (MP4); „Norisi rodyti } \\
\text { jiems [vaikams] tinkama pavyzdi“ (MP5). }\end{array}$ \\
\hline & $\begin{array}{l}\text { Finansinès, } \\
\text { materialinès ir } \\
\text { nematerialinès } \\
\text { paskatos }\end{array}$ & $\begin{array}{l}\text { „Tai finansiniai dalykai“ (MP3); „Manau, kad vadu pasitikejjimas, } \\
\text { apdovanojimai, ivertinimai, paskatinimai“(MP6); „Labiausiai skatina } \\
\text { aplinka: geras kolektyvas, geri kolegos, kurie vieni kitiems padeda, esant } \\
\text { reikalui, manau, čia yra didžiausias skatinimas“ (MP8). }\end{array}$ \\
\hline & $\begin{array}{l}\text { Galimybė siekti } \\
\text { vertikalios karjeros }\end{array}$ & $\begin{array}{l}\text { „Skatina karinis laipsnis“ (MP1); „Aišku, labiausiai mane skatina tai } \\
\text { aukštesnis karinis laipsnis“ (MP6). }\end{array}$ \\
\hline & $\begin{array}{l}\text { Individualus } \\
\text { kiekvienos moters } \\
\text { karès požiūris / siekis }\end{array}$ & $\begin{array}{l}\text { „<...> viskas labai priklauso nuo asmeninio požiūrio }<\ldots>^{\prime} \text { (MP2); } \\
\text { „Moterys, kurios turi tikslą ir atitinkamų savybių, tikrai gali pasiekti } \\
\text { karjeros aukštumų kariuomenèje“ (MP7). }\end{array}$ \\
\hline
\end{tabular}

Šaltinis: sudaryta autorių.

Atlikus tyrimą pastebėta, jog nemažai tiriamujjų (3 moterys karès) akcentavo, kad moteru karjerą Lietuvos kariuomenejje skatina vienas ypač svarbus vidinis veiksnys - tai vidinė motyvacija, kurios šaltiniai yra nuolatinis noras įrodyti, kad moteris nėra prastesnè karė nei vyras, noras būti pavyzdžiu kitoms moterims karėms, pastebima neteisybė/nelygybė kariuomenèje, kuri motyvuoja labiau siekti karjeros, ịveikti karjeros kliūtis, o taip pat siekis panaudoti asmenines žinias, igytą išsilavinimą ir individualius gebejjimus Tèvynès labui bei noras rodyti tinkamą pavyzdị vaikams.

Pusè tyrimo dalyvių (4 moterys karès) pažymėjo, kad moterų karjerą Lietuvos kariuomenėje itin skatina išoriniai veiksniai - finansinès, materialinès ir nematerialinès paskatos. Nors interviu dalyvès nenurodė konkrečių finansinių paskatų, tačiau joms galima priskirti darbo užmokestį, premijas, priedus prie atlyginimo ir pan. Prie materialinių paskatų priskirtini interviu dalyvių akcentuoti apdovanojimai, o prie nematerialinių paskatų, suteikiančių moterims karèms moralini pasitenkinimą, priskirtina vadų rodomas pasitikèjimas, suteiktos atsakingos pareigos, gera ir 
draugiška aplinka ir pan. Galimybe siekti vertikalios karjeros yra dar vienas išorinis veiksnys, kuris skatina moteris siekti karjeros Lietuvos kariuomenèje. Š $\breve{i}$ aspektą pažymèjo trys moterys karès. Jos galimybę siekti vertikalios karjeros traktavo kaip aukštesnio karinio laipsnio gavimą. Dalis tiriamujų ( 2 moterys karès) manè, kad moterų karjeros Lietuvos kariuomenejje skatinimo rezultatai labai priklauso nuo individualaus kiekvienos moters karès požiūrio/siekio. Buvo pastebètas moterų pasitikejjimas savo jègomis. Tai patvirtina teiginys, kad moterys, turinčios „tikslą ir atitinkamų savybių, tikrai gali pasiekti karjeros aukštumų kariuomenèje“ (MP7).

Moteru karjerai Lietuvos kariuomenèje trukdantys veiksniai. Analizuojamoje kategorijoje tiriamųjų atsakymai buvo sugrupuoti ị 5 subkategorijas (žr. 7 lentelę).

Lentele 7. Moterų karjerai Lietuvos kariuomenèje trukdantys veiksniai

\begin{tabular}{|c|c|c|}
\hline KATEGORIJA & SUBKATEGORIJOS & İRODANTYS TEIGINIAI \\
\hline \multirow[t]{6}{*}{$\begin{array}{l}\text { Moterų karjerai } \\
\text { Lietuvos kariuo- } \\
\text { menëje } \\
\text { trukdantys } \\
\text { veiksniai }\end{array}$} & $\begin{array}{l}\text { Stereotipai, formuojantys } \\
\text { neformalias kliūtis } \\
\text { moterims siekti karjeros }\end{array}$ & 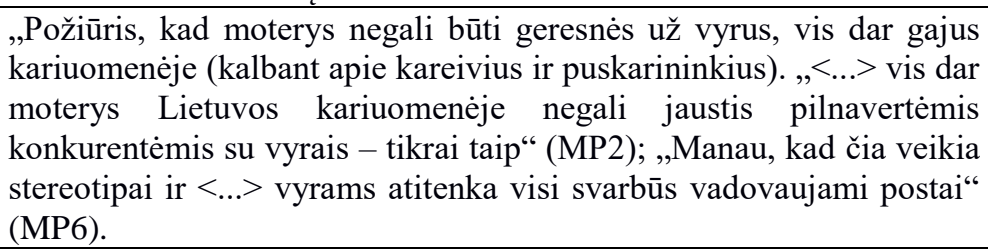 \\
\hline & $\begin{array}{l}\text { Asmeninis vadų požiūris } \\
\text { i moteris kares } \\
\text { (asmeniškumai) }\end{array}$ & $\begin{array}{l}\text { „Tol, kol sprendimus priimančiose pozicijose bus kariai vyrai, kurie } \\
<\ldots .>\text { tarnauja nuo Nepriklausomybès pradžios, tol nelabai kas nors ir } \\
\text { pasikeis, nes jų asmeninis požiūris labai ribotas }<\ldots \text {.. }>\text { “ (MP2); „Kaip ir } \\
\text { visur yra, asmeniškai priklauso nuo vadų požiūrio“ (MP3); „Žinoma, } \\
\text { atskirais atvejais pasitaiko skirtingo vadų, viršininkų požiūrio i } \\
\text { moteris, ir tai gali nulemti jų karjera“" (MP7). }\end{array}$ \\
\hline & $\begin{array}{l}\text { Pamainos darbo vietoje } \\
\text { nebuvimas }\end{array}$ & $\begin{array}{l}\text { „Asmeniškai trukdo, mano manymu, tai, kai esi vienas skyriuje be } \\
\text { karių, kurie tave galètu pavaduoti išeinant i kursą“ (MP3); „<..> } \\
\text { pirmiausia turi atlikti savo darbus, jeigu esi tokiose pareigose, kur tavo } \\
\text { nebuvimas reiškia darbų stabdymą ir niekas pavaduoti negali, tada } \\
\text { labai sunku išvažiuoti i kursus, nes }<\ldots>\text { nèra, kas už tave } \\
\text { dirbs“ (MP5). }\end{array}$ \\
\hline & $\begin{array}{l}\text { Karjeros neskatinanti } \\
\text { darbo aplinka }\end{array}$ & $\begin{array}{l}\text { „Negaliu pasakyti, kad kas nors skatina darbo aplinkoje, tik žlugdo“ } \\
\text { (MP4); „Skatinimo iš aplinkos nėra < ... >“ (MP1). }\end{array}$ \\
\hline & $\begin{array}{l}\text { Moterų neitraukimas ị } \\
\text { sprendimų prièmimą }\end{array}$ & $\begin{array}{l}\text { „Beje, svarstymuose ir sprendimų prièmime moterys taip pat } \\
\text { nedalyvauja arba dalyvauja minimaliai, tad kol kas tikètis kažko } \\
\text { daugiau vilčių nedaug }<\ldots \text {..." (MP2). }\end{array}$ \\
\hline & $\begin{array}{l}\text { Moteru susitaikymas su } \\
\text { esama padėtimi }\end{array}$ & $\begin{array}{l}\text { „Deja, bet moterys ir pačios per greitai pasiduoda, nuleidžia rankas ir } \\
\text { nesiekia užimti lygiaverčiu poziciju su kariais vyrais“(MP2). }\end{array}$ \\
\hline
\end{tabular}

Šaltinis: sudaryta autoriu.

Išanalizavus informančių nuomonę apie moterų karjerai trukdančius veiksnius Lietuvos kariuomenejje, buvo nustatyta, kad, anot tiriamujų, didžiausia problema Lietuvos kariuomenèje yra stereotipai, kurie formuoja neformalias kliūtis moterims siekti karinès karjeros. Ṣ̌ veiksnị ịvardijo pusė tyrimo dalyvių (4 moterys karès), akcentuodamos ịvairius stereotipų aspektus. Asmeninị vadų požiūrị ị moteris kares (asmeniškumus) akcentavo trys tyrimo dalyvès. Dèl asmeniškumų gali būti ignoruojami moterų karių nuopelnai, ribojamos jų karjeros galimybès, paskiriant i aukštesnes pareigas vyrus karius. Reikia pažymèti, kad asmeniškumai yra glaudžiai susiję su stereotipais, nes asmeninis vadų požiūris i moteris kares rodo stereotipines nuostatas (pavyzdžiui, teigiama, kad moterys prastesnès karès negu vyrai ir pan.).

Tuo tarpu tik viena puskarininkè nurodè, kad jokių veiksnių, kurie trukdytų moterų karjerai Lietuvos kariuomenèje, nėra. Tokia nuostata, manytina, grindžiama asmenine karès patirtimi ir galbūt mažesnėmis ambicijomis, siekiant karinès karjeros (jos išsilavinimas yra vidurinis, o turimas karinis laipsnis - seržanto).

Pastebėta, kad tos moterys karès, kurios neįžvelgè moterų karjerai kariuomenèje trukdančių veiksnių, akcentavo, kad tarp moterų ir vyrų egzistuoja lygios galimybės siekti karinès karjeros ir kad moterų vertikalios karinès karjeros galimybės yra realios. Šios karès teigiamai vertino moterų karjeros 
galimybes šalies kariuomenèje. Vis dèlto likusi interviu dalyvių dalis buvo kritiškesnè: ne tik akcentavo stereotipus ir vadų asmeniškumus, bet ir nurodė daugiau trukdančių veiksnių - pamainos darbo vietoje nebuvimą, neskatinančią darbo aplinką, moterų neịtraukimą ị sprendimų priemimą. Buvo akcentuojama ir tai, kad moterys karès dažnai susitaiko su esama padètimi ir aktyviai nesiekia karinès karjeros.

Taigi, galima teigti, kad moterų karjerai Lietuvos kariuomenejje trukdantys veiksniai iš esmès yra išoriniai (stereotipai, vadų asmeniškumai, pamainos darbo vietoje nebuvimas, neskatinanti darbo aplinka, moterų neịtraukimas ị sprendimų priẻmimą). Tik vieną veiksnị - moterų susitaikymą su esama padètimi - galima priskirti vidinių veiksnių kategorijai, tačiau, manytina, kad šị veiksnị reikètų laikyti ne tiek priežastimi, trukdančia moterims siekti karinès karjeros, kiek aukščiau išvardintų išorinių veiksnių pasekme.

Atlikus analizę pastebėta, jog, kaip teigia Duncanson ir kt. (2016) ir Hayward (2018), gerèja moteru karjeros galimybės NATO narių, tarp jų ir Lietuvos, kariuomenejje. Tai liudija moterų skaičiaus augimas mūsų šalies karinèse pajègose. İtakos tam turi karinių technologijų modernejjimas, didèjantis specializuotų žinių poreikis ir kt.

Moterų norą susieti savo profesinę veiklą su karine organizacija gali paskatinti žinojimas, kad kariuomenèje egzistuoja reali moterų kilimo karjeros laiptais galimybè, kurią užtikrina šalyje veikianti teisine bazé, garantuojanti vienodas galimybes siekti karinès karjeros moterims ir vyrams (pvz., KASOKTİ, 1998, ir kt.). Empirinio tyrimo eigoje nustatyta, kad puskarininkès yra susipažinusios su teisine baze, reglamentuojančia jų profesinę veiklą ir vertino ją palankiai.

Kaip teigia Kamarck (2016) bei Rosellini ir kt. (2017), moterys dèl savo lyties susiduria su ịvairias sunkumais ir kliūtimis darydamos kario profesinę karjerą, nors teisinė bazė ir reglamentuoja lygias moterų ir vyrų teises. Tyrime dalyvavusios karès savo atsakymais tai patvirtino. Jos teigè, kad egzistuoja kliūčių, susijusių su lytimi, kurios trukdo puskarininkẻms siekti karinès karjeros (pvz., joms sunku užimti tokias pareigas, kaip būrio vado pavaduotojo, kuopininko, bataliono puskarininkio ir pan.). Neretai, tyrimo dalyvių nuomone, panašius gebejjimus ir patirtį turinčiam kandidatui vyrui teikiamas didesnis pranašumas už kandidatę moterị. Tokiu būdu, kaip teigia Vilniškytė ir kt. (2019), moterys susiduria su ,stiklinių lubų“ fenomenu, kurị, pasak Sharma ir Kaur (2019), lemia asmeninès, organizacinès ir socialinès kliūtys. Anot tyrimo dalyvès, šį fenomeną iš dalies galètų padèti ịveikti moterų karių įtraukimas ị sprendimų prièmimo procesą.

Kariuomenei būdingas konservatyvus (biurokratinis) požiūris ị karjerą. Kadangi kariuomenè yra statutiné organizacija, kuriai būdinga hierarchija su aiškia subordinacija, toks požiūris yra neišvengiamas. Lietuvos kariuomenèje, kaip biurokratinèje organizacijoje, karių karjera yra susieta su vertikalios ir horizontalios karjeros galimybėmis (pvz., Petkevičiūte, 2013, ir kt.). Kadangi karjera - tai žmogaus išraiškos priemone ir galimybe išnaudoti žmogiškaji potencialą, kaip tvirtina Hambly ir kt. (2019), ị tai yra orientuotos puskarininkès tyrimo dalyvès teigia, kad jos norètų siekti ir horizontalios, ir vertikalios karjeros, išnaudodamos savo žinias, gebèjimus ir sukauptą patyrimą. Tačiau, pasak tiriamujų, moterų horizontali karjera neretai Lietuvos kariuomenejje naudojama kaip moterų vertikalios karjeros alternatyva, t. y. patenkinami moterų karių lūkesčiai dèl horizontalios karjeros, kad nereikètų tenkinti jų lūkesčių dèl vertikalios karjeros. Taip pat informantès mano, kad moterims karèms egzistuoja mažiau neformalių kliūčių siekti horizontalios, nei vertikalios karjeros.

Lamanauskas ir kt. (2015b) teigia, kad karjerą skatinančius veiksnius galima suskirstyti i vidinius ir išorinius. Būtent šios dvi grupès veiksnių ir buvo išskirtos tyrimo dalyvių atsakymuose. Informančių nuomone, moterų karjerą Lietuvos kariuomenejje skatinančių vidinių veiksnių grupei priskirtina vidinè motyvacija, individualus kiekvienos moters karès požiūris/siekis ir kt., o prie išorinių - finansinès, materialinès bei nematerialinès paskatos ir kt. Šių grupių veiksnių dermé arba atskiri jų komponentai daro skatinantị poveikị ir teigiamai veikia moterų norą siekti karjeros mūsų šalies kariuomenejje. Kaip labiausiai kliudančius veiksnius siekiant moterims karèms profesinès karjeros tyrimo dalyvès nurodè vis dar egzistuojančius stereotipus ir asmeninị vadovų požiūrị i moterų karjerą bei Hirschi ir kt. (2018) akcentuotą organizacijos narių (analizuojamu atveju moterų) neįtraukimą ị sprendimų prièmimo procesą. 


\section{Išvados}

1. Šiuolaikiniu požiūriu karjera reiškia asmens darbo ir mokymosi patirčių seką, besitęsiančią visą žmogaus gyvenimą. Konservatyvioji (biurokratinè) karjera pabrèžia linijinį karjeros siekimo būdą ir iškelia organizacijos interesų pirmumą prieš darbuotojo interesus. Šio modelio šalininkai išskiria dvi karjeros rūšis, t. y. horizontalią ir vertikalią. XXI amžiuje karjera yra orientuota $\mathfrak{i}$ asmens savybes, individo fizini ir psichologini mobilumą, todèl siekis suderinti darbuotojo ir organizacijos interesus yra svarbus nūdienos karjeros bruožas. Karjerą galima traktuoti kaip sistemą, kuriai įtaką daro ịvairūs - vidiniai/asmenybiniai (t. y. ịsitikinimai, gebejjimai, interesai, vertybės ir kt.) ir išoriniai (t. y. šeima, draugai, mokymo ịstaiga, bendruomenè, darbo rinka ir kt. ) veiksniai. Asmuo, skatinamas savo vidinių poreikių ir atsižvelgdamas i supančios aplinkos daromą poveikị bei jos keliamus iššūkius, kuria savo karjeros kelią. 1998 m. prièmus LR Moteru ir vyru lygiu galimybiu istatyma (1998) ir jo pagrindu sudarius teisines prielaidas, realiai užtikrinančias lygių moterų ir vyrų teisių igyvendinimą, buvo oficialiai itvirtinta moterų teisé tarnauti Lietuvos kariuomenejje. XXI amžiaus pradžiai būdingas kariuomenès virsmas iš modernios ị postmodernią, kuri toleruoja ir pripažista moterų vaidmenị kariuomenèje. Visgi moterų karių Lietuvos kariuomenèje nèra daug (2019 m. moterys sudarè 12,1 proc. šalies profesinès karo tarnybos karių). Pastebėtina, kad moterys siekdamos karjeros kariuomenèje kartais susiduria su „stiklinių lubų“ fenomenu.

2. Pagrindinis teisinis dokumentas reglamentuojantis karių karjerą Lietuvos kariuomenejje yra LR Krašto apsaugos sistemos organizavimo ir karo tarnybos ịstatymas (1998), kuris nustato KAS organizavimo, valdymo ir kontrolès pagrindus, karo tarnybos atlikimo tvarką. Minètas dokumentas yra nuolat tobulinamas, ir todèl per visą jo gyvavimo laikotarpi buvo atlikta daugiau nei 50 jo pakeitimų. Šis dokumentas reglamentuoja karių laipsnių skyrimo tvarką, karių tarnybos apmokejjimo ir aprūpinimo tvarką, t. y. visą tai, kas turi ịtakos kariams, siekiant karjeros Lietuvos kariuomenejje. Dokumente pabrěžiama, kad moterų ir vyrų tarnybos sąlygos (atlyginimų, priedų ir kitų išmokų skyrimo ir mokejjimo, kitos materialinio aprūpinimo sąlygos) yra vienodos, taip pat moterims ir vyrams užtikrinamos vienodos socialinès garantijos. Kiti teisiniai dokumentai reglamentuojantieji karių karjerą kariuomenejje yra: KAS personalo politikos koncepcija (2017), kurioje apibūdinama bendra karinio personalo karjeros sistema ir joje išskirti svarbiausi KAS karinio personalo karjeros planavimo bei organizavimo politikos aspektai; Lietuvos kariuomenès logistinès krypties kareiviu ir puskarininkiu rengimo ir karjeros gairès (2016), apibrezžiančios kareivių ir puskarininkių (žemiausios ir vidurinès kariuomenès grandies) karjeros lygmenį; Karininku karjeros koncepcija (2012), kurioje yra suformuluotos KAS karininkų karjeros sistemos gairès, organizavimo principai, koncepcijos ịgyvendinimo formos ir būdai. Griežtas karjeros reglamentavimas rodo, kad kariuomenei būdingas biurokratinis požiūris ị karjerą, tačiau žinant, kad kariuomenė yra statutinè organizacija, kuriai būdinga hierarchija su aiškia subordinacija, toks požiūris yra neišvengiamas. Lietuvos kariuomenejje karių karjera yra susieta su vertikalios ir horizontalios karjeros galimybėmis.

3. Atlikus interviu su moterimis puskarininkèmis, nustatyta, kad, didžiosios dalies tyrimo dalyvių nuomone, teisinè bazè, reglamentuojanti karjerą Lietuvos kariuomenèje, yra vienoda tiek moterims, tiek vyrams, todėl teisiniu požiūriu galimybės siekti karjeros abiejų lyčių atstovams yra palankios. Visgi dalis puskarininkių nurodè, kad teisinė bazė yra nepakankamai palanki néščioms ir vaikų priežiūros atostogose esančioms moterims. Taip pat nustatyta, kad žemesnio išsilavinimo moterys karès vertino teisinę bazę reglamentuojančią karjerą kariuomenèje palankiau nei turinčios aukštesnị išsilavinimą. Taigi darytina prielaida, kad moterų karių požiūris ị teisinę bazę iš dalies priklausė nuo moterų karių igyto išsilavinimo. Tyrimo rezultatai liudija, kad nors, anot Duncanson ir kt. (2016) ir Hayward (2018), gerejja moterų karjeros galimybės NATO narių kariuomenėse, bet, pasak Duncason ir kt. (2016), kariuomenè vis dèlto yra viena iš „vyriškos profesijos“ sričių, todèl neatsitiktinai didesnè dalis tiriamų moterų karių manè, kad jų galimybès, lyginant su vyrais, siekti karjeros Lietuvos kariuomenejje nèra lygios, jog egzistuoja akivaizdus vyrų pranašumas prieš moteris, siekiant karjeros tam tikrose pareigose, t. y. susiduriama su „stiklinių lubų“ fenomenu, kurį, anot Sharma ir Kaur (2019), lemia asmeninès, organizacinès ir socialinès kliūtys. Ši fenomeną, pasak tiriamųjų, iš dalies galètų padèti įveikti moterų karių įtraukimas ị sprendimų prièmimo procesą, ką 
pastebi ir Hirschi bei kt. (2018). Didesnioji dalis puskarininkių tyrimo dalyvių manė, kad moterų karių galimybės siekti vertikalios karjeros Lietuvos kariuomenejje yra ribotos ir prastesnès, lyginant su jų horizontalios karjeros galimybėmis. Išanalizavus tiriamųjų nuomonę apie veiksnius, skatinančius ir kliudančius moterims daryti karjerą kariuomenejje, buvo nustatyta, kad tyrime dalyvavusias puskarininkes skatina vidiniai (vidinè motyvacija, individualus moters karès požiūris/siekis) ir išoriniai (finansinès, materialinės ir nematerialinès paskatos, galimybè siekti vertikalios karjeros) veiksniai. Labiausiai moterų karių karjerai Lietuvos kariuomenèje, informančių nuomone, trukdo išoriniai veiksniai, pvz., stereotipai, vadų asmeniškumai, neskatinanti darbo aplinka, moterų neįtraukimas ị sprendimų prièmimo procesą.

\section{Literatūra}

1. Aleknevičienè, J. Lygių karjeros galimybių krašto apsaugos sistemoje analizè. Vilnius: LKA, $2013 a$. https://kam.lt/download/46228/priedas\%202.pdf

2. Aleknevičienè, J. Moterų padètis krašto apsaugos sistemoje. Vilnius: LKA, $2013 \mathrm{~b}$. https://kam.lt/download/46227/priedas\%201.pdf

3. De Vos, A., Vander Heijden, B. J. M., Akkermans, J. Sustainable careers: Towards a conceptual mode. Yjvbe, 2018 doi:10.1016/j.jvb.2018.06.011

4. Duncanson, C. P., Woodward, R. Regendering the military: theorizing women's military participation. Security Dialogue, 2016, 47 (1), p. 3-21.

5. Evertson, A., Nesbitt, A. The glass ceiling effect and its impact on mid-level female officer career progression in the United States Marine Corps and Air Force. Dissertation, USA, 2004. https://calhoun.nps.edu/bitstream/handle/10945/1711/04Mar_Evertson.pdf?sequence=1\&isAllowed=y

6. Gaižauskaitè, I., Valavičienė, N. (2016). Socialinių tyrimų metodai: kokybinis interviu. Vilnius: MRU leidybos centras.

7. Generolo Jono Žemaičio Lietuvos karo akademijos Statutas. Vilnius: LKA, 2015.

8. Generolo Jono Žemaičio Lietuvos karo akademijos Strategija 2018-2024. Vilnius: LKA, 2018.

9. Gražulis, V., Račelytė, D., Dačiulytė, R., Valickas, A., Adamonienè, R., Sudnickas, T., Raišienè, A. G. Žmogiškuju išteklių valdymas. Vilnius: MRU leidybos centras, 2015.

10. Guščinskienè, J., Čiburienè, J. I studentą sutelktos studijos kaip karjeros kūrimo prielaida. Šiuolaikinès visuomenès ugdymo veiksniai, 2018, 3, p. 167-182.

11. Hayward, L. Increasing the Number of Senior Women in the Australian Army. Security Challenges, 2018,14 (2), p. 37-48.

12. Hambly, L., Bomford, C. Creative Career Coaching: Theory into Practice. London and New York: Routledge, 2019.

13. Hirschi, A., Nagy, N., Baumeler, F., Johnston, C. S., Spurk, D. Assessing Key Predictors of Career Success: Development and Validation of the Career Resources Questionnaire. Journal of Career Assessment, 2018,26 (2), p. 338-358.

14. KAM Personalo departamento duomenys. Vilnius: LR KAM, 2019.

15. Kamarck, K. N. Women in Combat: Issues for Congress, 2016. https://fas.org/sgp/crs/natsec/R42075.pdf

16. Karininkų karjeros koncepcija. Vilnius: KAM, 2012.

17. Korsakienè, R., Smaliukienė, R. Šiuolaikinè karjera individo požiūriu: karjeros modeliai, jų sąsajos ir reikšmė. Verslas: Teorija ir praktika, 2014, 15 (1), p. 84-92.

18. Krašto apsaugos sistemos personalo politikos koncepcija. Vilnius: KAM, 2017.

19. Lamanauskas, V., Augienė, D. Universiteto studentų karjeros supratimas, darbo vertybių, kompetencijų ir studijų įtakos profesinei karjerai vertinimas. Švietimas: Politika, vadyba, kokybė, 2015a, 7 (1), p. 8-26.

20. Lamanauskas, V., Augienè, D. Universiteto studentų profesinè karjera: supratimo struktūra. Švietimas: Politika, vadyba, kokybè, 2015b, 7 (3), p. 106-117.

21. Lietuvos kariuomenès logistinès krypties kareivių ir puskarininkių rengimo ir karjeros gairès. Vilnius: Lietuvos kariuomenès Logistikos valdyba, 2016.

https://kam.lt/download/57462/rengimo\%20ir\%20karjeros\%20gair\%C4\%97s1.pdf

22. Lietuvos Respublikos krašto apsaugos sistemos organizavimo ir karo tarnybos įstatymas. Žin., 1998, Nr. 49-1325.

23. Maslauskaite, A. Moterų padètis ir karjeros galimybès Lietuvos krašto apsaugos sistemoje. Karo archyvas, 2006, 21, p. 277-314.

24. MPB „Geležinis Vilkas“ vidiniai duomenys, 2019.

25. Neary, S., Dodd, V., Hooley, T. Understanding career management skills: findings from the first phase of the CMS LEADER project. Derby: University of Derby, 2016. http://hdl.handle.net/10545/595866

26. Orenius, A., Pitrènaitė, B. Moters karjeros problema Lietuvos kariuomenejje. Viešoji politika ir administravimas, 2005,12, p. 119-125.

27. Petkevičiūtè, N. Vadovo karjeros vystymo metamorfozès. Organizacijų vadyba: sisteminiai tyrimai, 2007, 42, p. 93110 . 
28. Petkevičiūtè, N. Karjeros valdymas: organizacinė perspektyva. Kaunas: VDU leidykla, 2013.

29. Raudeliūnas, R., Valickas, A. Karininkų karjeros valdymas krašto apsaugos sistemoje: problemos ir tobulinimo perspektyvos. Viešoji politika ir administravimas, 2018, 17 (2), p. 298-310.

30. Rosellini, A. J., Street, A. E., Ursano, R. J. ir kt. Sexual assault victimization and mental health treatment, suicide attempts, and career outcomes among women in the US Army. AmJ Public Health, 2017, 107 (5), p. $732-739$.

31. Sharma, S, Kaur, R. Glass Ceiling for Women and Work Engagement: The Moderating Effect of Marital Status. FIIB Business Review, 2019, 8 (2), p. 132-146. https://doi.org/10.1177/2319714519845770

32. Summary of the National Reports of NATO Member and Partner Nations to the NATO Committee on Gender Perspectives-2015, 2017.

https://www.nato.int/nato_static_fl2014/assets/pdf/pdf_2017_01/20170113_2015_NCGP_National_Reports_Summ ary.pdf

33. Summary of the National Reports of NATO Member and Partner Nations to the NATO Committee on Gender Perspectives-2016, 2018. https:/www.nato.int/nato_static_fl2014/assets/pdf/pdf_2018_01/1801-2016-SummaryNR-to-NCGP.pdf

34. Summary of National Reports of NATO Member and Partner Nations to the NCGP-2017, 2019. https://www.nato.int/nato_static_fl2014/assets/pdf/pdf_2019_09/20190909_190909-2017-Summary-NR-toNCGP.pdf

35. Šidlauskienè, V.S. „Stiklo lubų“ fenomenas moterų profesinès karjeros raidoje / Virginija Šidlauskienė. Lyčių studijos ir tyrimai: teminis straipsnių rinkinys. Šiauliai: VšI Šiaulių universiteto leidykla, 2005, p. 17-22.

36. Vileikienè, E., Pocienė, A., Aleknevičienè, J. Motyvacija tarnauti Lietuvos kariuomenèje: mokslo studija. Vilnius: Generolo Jono Žemaičio Lietuvos karo akademija, 2015.

37. Vilniškytė, K., Skarbalienė, A. Moterų lyderystès mastas pasaulyje. Akademinio jaunimo siekiai: ekonomikos, vadybos, teisès ir technologijų įžvalgos. Klaipèda: Lietuvos verslo kolegija, 2018, p. 53-59.

38. Wilén, N., Heinecken, L. Regendering the South African army: Inclusion, reversal and displacement. Gender Work \& Organization, 2018, 25 (6), p. 670-686.

39. Williams, L. S. M., McGivern, M.H. Women in the Military Who Have Shattered the Glass Ceiling: A Phenomenological Study. International Journal of Strategic Information Technology and Applications, 2017, 8 (1), p.1-20. https://dl.acm.org/doi/abs/10.4018/IJSITA.2017010101

40. Žydžiūnaitè, V. Baigiamojo darbo rengimo metodologija: mokomoji knyga. Klaipėda: Vitae litera, 2011.

41. Žydžiūnaitė, V., Sabaliauskas, S. Kokybiniai tyrimai: principai ir metodai. Vadovèlis socialinių mokslų studijų programų studentams. Vilnius: Vaga, 2017.

\title{
Deimantas Pleskys, Jūratė Guščinskienė
}

\section{Careers of Women Soldiers in the Lithuanian Army: The Opinion of Female Non-Commissioned Officers}

\begin{abstract}
The aim of this research paper is to examine the career prospects of female soldiers in the Lithuanian Armed Forces. The article tackles the concept of career and legal regulation of careers in the military. The empirical part of the paper is based on an original survey of female noncommissioned officers' opinion, which was conducted at the end of 2019 at the command of the Mechanized Infantry Brigade "Iron Wolf". The opinion of female non-commissioned officers showed that the legal basis of career making for all soldiers in the Lithuanian Armed Forces is the same for both women and men, but some of the participants in the study pointed out that this is not sufficiently relevant to pregnant women and women on maternity leave, as, for example, women on maternity leave are often transferred to the personnel reserve, and their positions are filled by other soldiers, etc. The respondents' opinion on women's opportunities to pursue a career in the Lithuanian Armed Forces compared to men was divided, as some of the respondents believed that women and men have equal opportunities in all areas of their professional activities, while others stated that opportunities are equal only in administration, service and similar areas. It was found that some female NCOs find it difficult to pursue a vertical military career on equal terms with men, that few female soldiers are in senior positions in the army, in other words, women often face the phenomenon of the 'glass ceiling' when pursuing vertical careers. In contrast, there are better opportunities for women soldiers to pursue horizontal careers in the army. Factors that encourage women's careers in the military include their personal motivation and financial, material and non-material incentives, while those that
\end{abstract}


hinder them include the stereotypes that still exist in the military, the personalities of commanders, the exclusion of women from decision-making processes, etc.

Deimantas Pleskys, Chief Specialist, Logistics Department of the Ministry of National Defense Republic of Lithuania

E-mail: deimantas.pleskys@gmail.com

Jūratė Guščinskienè, Assoc. Professor of Defense Economics and Management Research Group, General Jonas Žemaitis Military Academy of Lithuania

E-mail: jurate.guscinskiene@1ka.lt

Deimantas Pleskys, vyriausiasis specialistas, Lietuvos Respublikos krašto apsaugos ministerijos Logistikos departamentas

El. paštas: deimantas.pleskys@ gmail.com

Jüratè Guščinskiené, Gynybos ekonomikos ir vadybos mokslo grupès docentè, Generolo Jono Žemaičio Lietuvos karo akademija

El. paštas: jurate.guscinskiene@ @ lka.lt 